DOI: https://doi.org/10.24867/15CG11Marjanovic

\title{
UPOREDNA ANALIZA KLASA DUKTILNOSTI PREMA EVROKODU USLED PREKORAČENJA PRORAČUNSKOG UBRZANJA TLA
}

\section{COMPARATIVE ANALYSIS OF DUCTILITY CLASSES ACCORDING TO EUROCODE DUE TO EXCEEDING OF DESIGN GROUND ACCELERATION}

\author{
Đorđe Marjanović, Đorđe Lađinović, Fakultet tehničkih nauka, Novi Sad
}

\begin{abstract}
Oblast - GRAĐEVINARSTVO
Kratak sadržaj - Predmet rada obuhvata postojeću armiranobetonsku konstrukciju projektovanu u DCM klasi duktilnosti za ubrzanje tla $a_{g R}=0,25 \mathrm{~g}$ (povratni period od 475 god). Konstrukcija je izložena ubrzanju tla većem od projektovanog $\left(a_{g R}=0,35 \mathrm{~g}\right)$ pri čemu je promjenom u DCH klasu duktilnosti potrebno dokazati da se uz minimalne korekcije u smislu dimenzija presjeka $i$ količine armature, može zadovoljiti EC2 $i$ EC8 propis $i$ dobiti upotrebljiva konstrukcija.
\end{abstract}

Ključne reči: Višespratna armiranobetonska zgrada, Evrokodovi, seizmička analiza, ukrućeni skeletni sistem, statički proračun, dimenzionisanje, plan armiranja, poređenje konstrukcija, klase duktilnosti, ubrzanje tla

Abstract - Subject of the thesis is the existing structure designed for ground acceleration $a_{g R}=0,25 \mathrm{~g}\left(T_{R}=475 \mathrm{yrs}\right)$. This RC structure is exposed to soil acceleration $a_{g R}=0,35 \mathrm{~g}$ and redesigned to DCH ductility class, with intention to attest that small correction of geometry and quantity of reinforcement is possible to fulfill EC2 and EC8 standards and to make the structure usable.

Keywords: Multi storey RC structure, Eurocodes, seismic analysis, RC frame with shear walls, static design, structural design and reinforcement plans, comparison of structures, ductility classes, ground acceleration

\section{UVOD}

Konstrukcija koja je prethodno izvedena svrstava se $\mathrm{u}$ skeletni sistem ukrućen duktilnim zidovima. Način armiranja i nosivost armiranobetonskih primarnih seizmičkih elemenata (stubovi i grede) zadovoljava DCM klasu duktilnosti. Tako projektovana konstrukcija izložena je znatno većem seizmičkom dejstvu od projektnog. Analizom uticaja i drugih parametara poput međuspratnih pomijeranja, relativne rotacije primarnih seizmičkih elemenata zaključuje se da li će doći do pojave plastičnih zglobova i na kojim mjestima. Postojeća konstrukcija pokazaće se kao neadekvatna za veći nivo seizmičkog dejstva, što može biti problem zbog učestalih zemljotresa čiji nivo oslobođene energije sve češće prekoračuje vrijednosti date mapama seizmičkog hazarda.

\section{NAPOMENA:}

Ovaj rad proistekao je iz master rada čiji mentor je bio dr Đorđe Lađinović, red. prof.
Racionalnim projektovanjem prvobitne konstrukcije izvijesno je da neće zadovoljiti parametre za veće ubrzanje. Suština projektnog zadatka počinje od tog dijela analize gdje je neophodno dokazati da će se, računajući na manje uticaje povećanjem faktora ponašanja i uz poštovanje propisa datih u EC8, zadovoljiti standard i dobiti dovoljno duktilna konstrukcija da prihvati novi nivo opterećenja.

Zapravo, povećanje faktora ponašanja nije ništa drugo nego da projektant svjesno umanji nosivost na račun duktilnosti. Zapravo, konačni cilj i tema zadatka jeste da se dokaže da li je u postojećim okolnostima racionalnije projektovati DCM ili DCH konstrukciju, s obzirom na učestale greške u predviđanju nivoa seizmičkog dejstva. Za rad nije rađena ekonomska analiza u smislu dodatnog materijala, trajanja i složenosti izvođenja radova, ali je iz uvida u druge relevantne izvore zaključeno da drastična razlika za objekte ovog nivoa složenosti konstrukcije zapravo ne postoji.

\section{ANALIZA KONSTRUKCIJE}

\subsection{Osnovni podaci}

Podaci o modelu, analiza opterećenja i druge generalije su preuzete iz projekta postojeće konstrukcije. Suština objekta ostala je nepromijenjena - raspored seizmičkh zidova, spratnost, raster stubova. Jedina značajna izmjena u konstrukciji je povećanje poprečnog presjeka stubova $\mathrm{u}$ oba pravca za po $5 \mathrm{~cm}$, kako bi u modalnoj analizi svi parametri bili u dozvoljenim granicama.

Ipak, oblikovanje detalja i uputstva iz EC8 za klasu DCH biće presudni za odgovor konstrukcije na uvećano zemljotresno dejstvo. U nastavku je prikazan prostorni model konstrukcije.

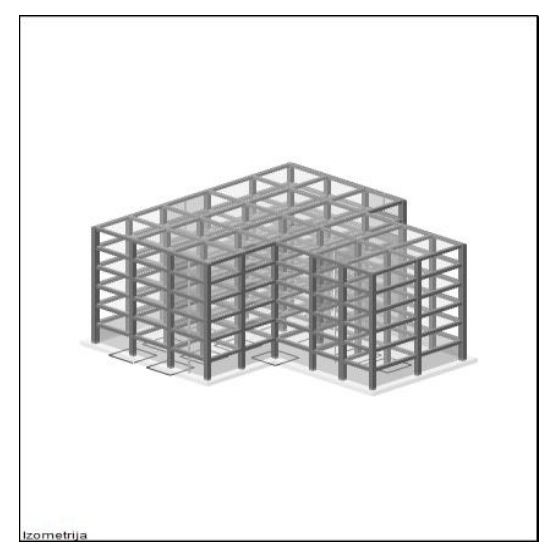

Slika 1. Prostorni model konstrukcije u Tower-u 


\subsection{Elementi konstrukcije}

Svi elementi konstrukcije projektovani su za klasu betona C30/37. Armatura za klasu DCM je B500B, a za klasu DCH je B500C. Razlika klase armature prikazana je u tabeli ispod.

\begin{tabular}{|c|c|c|c|}
\hline Čelik & $f_{y k}[\mathrm{MPa}]$ & $f_{t} / f_{y^{k}}[-]$ & $\varepsilon_{u k}[\%]$ \\
\hline B500A & 500 & 1.05 a) & 2.5 b) \\
\hline B500B & 500 & 1.08 & 5.0 \\
\hline B500C & 500 & $\geq 1.15, \leq 1.35$ & 7.5 \\
\hline a) Za prečnike manje od $8 \mathrm{~mm}$ & $-1.02 ;$ b) Za prečnike manje od $8 \mathrm{~mm}-1.0$ \\
\hline
\end{tabular}

Tabela 1. Različite klase armature

Dimenzije svih elemenata osim stubova novoformirane (DCH) konstrukcije su zadržane kao kod postojeće (DCM) konstrukcije. Stubovi su neznatno uvećani, po $5 \mathrm{~cm}$ u oba pravca, radi zadovoljenja određenih rezultata modalne analize. Dimenzije greda su $40 \mathrm{~cm} \times 50 \mathrm{~cm}$, a stubovi DCH konstrukcije su $55 \mathrm{~cm} \times 55 \mathrm{~cm}$. Debljina ploče tipskog sprata je $20 \mathrm{~cm}$, a temeljne ploče $60 \mathrm{~cm}$. Dužina tipskog, jednokrakog stepeništa je $550 \mathrm{~cm}$ i debljina ploče stepeništa je $22 \mathrm{~cm}$. Treba naglasiti da se adekvatnim oblikovanjem detalja i poštovanjem propisa EC8 za DCH klasu postiže visok nivo duktilnosti u konstrukciji, ali se velikom vrijednošću faktora ponašanja značajno redukuju sile u stubovima. Prema tome, armiranje temeljne ploče se mora sa posebnom pažnjom uraditi kako bi se izbjeglo probijanje ploče usljed neočekivanog nivoa sila. Temeljna ploča proširena je za $1 \mathrm{~m}$ sa svake strane, što je povoljno iz više razloga. U suterenu su čitavim obodom predviđeni $A B$ podrumski zidovi $\mathrm{d}=20 \mathrm{~cm}$. Iste debljine su i seizmički duktilni zidovi koji su postavljeni po 2 u svakom pravcu, na način da se dobiju optimalne karakteristike modela. Arhitektonski sklop je takav da dopušta za svaki zid da bude postavljen od dna do vrha zgrade, bez otvora, i to tako da povezuje 2 stuba između kojih se nalazi. Time je dobijen, a tako je i računat, zid „I“ presjeka što bitno olakšava zadovoljenje dilatacija u pritisnutom betonu i smanjenje zona utezanja krajeva zida. I platna i stepenište zadržali su dimenzije iz DCM modela, s tim da se armiranje DCH zidova značajno razlikuje od onih u DCM modelu. To je posebno naglašeno u vidu poprečne armature i uzengija za utezanje ivičnih zona.

\subsection{Analiza opterećenja}

Veći dio analize urađen je „ručno“ i dobijene vrijednosti unesene su u softver Tower 8 gdje su sopstvene težine konstrukcijskih elemenata generisane automatski na osnovu usvojenih dimenzija presjeka i klase betona. S obzirom na to da je namjena objekta isključivo stambena, sa skladišnim prostorom u suterenu, tako su analizirane samo 2 kategorije korisnog opterećenja na cijeloj konstrukciji - „A“ $\mathrm{A}$ “ „E“ kategorija. U dijelu „ručnog“ proračuna, sve težine preuzete su iz pojedinačne specifikacije za određeni materijal. Za temu master rada je ključno opterećenje seizmičko, jer je po prirodi nepredvidivo po vremenu pojave, smijeru, intenzitetu i drugim bitnim dinamičkim karakteristikama. Kao takvo, može se reći da je seizmičko opterećenje tema analize master rada. Intenzitet ubrzanja korišten za analizu DCH je:

$$
\mathrm{a}_{\mathrm{gR}}=0,35 \cdot \mathrm{g}=0,35 \cdot 9,81 \mathrm{~m} / \mathrm{s}^{2}=3,43 \mathrm{~m} / \mathrm{s}^{2}
$$

Klasa značaja je 2. i prema tome koeficijent sa kojim se množi referentno ubrzanje je 1 . Kategorija tla je 1, tip tla je B. U Evrokodu 8 su tabelarno prikazani parametri za svaki tip i kategoriju tla.

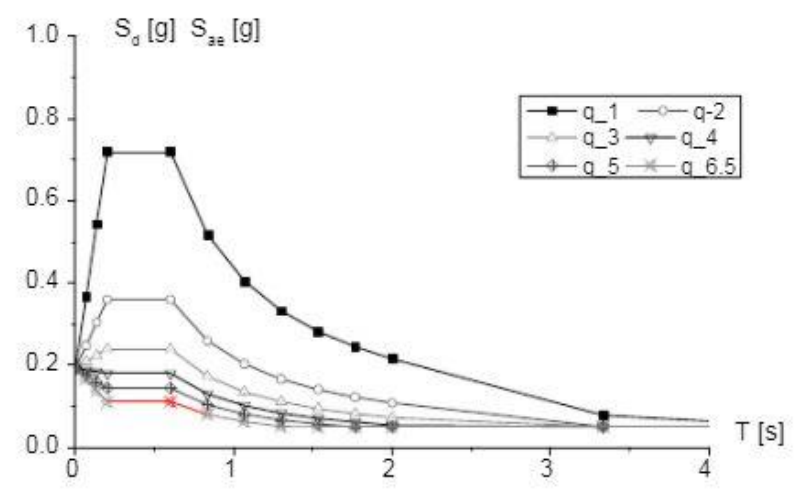

Slika 2. Redukovan elastični spektar za različite faktore ponašanja

U nedostatku zapisa ubrzanja (akcelerograma) pri simulaciji seizmičkog opterećenja koriste se spektri odgovora. Elastični spektar odgovora se u savremenoj praksi redukuje faktorom ponašanja, u mjeri pouzdanosti konstrukcije. Za klasu DCH očekuje se da će, poštujući EC8 propis i sve detalje koji su njime obrađeni, konstrukcija biti sposobna da se odupre visokom nivou opterećenja, a da pritom pomijeranja tj oštećenja ostanu u granicama postavljenih zahtjeva. Savremena praksa je u suprotnosti sa tradicionalnom, ali i sa ostatkom analize opterećenja gdje se koriste faktori sigurnosti i teži se ka tome da se elementi koji treba da prime ta optrećenja dimenzionišu da budu u granicama elastičnog rada. Ipak, ovim pristupom se primarni konstrukcijski elementi ciljano dovode u neelastičnu fazu rada pri pojavi visokog nivoa seizmičkog opterećenja.

\subsection{Modalna analiza}

Savremeni propisi, poput EC8, za određivanje seizmičkih uticaja koriste metod spektra odgovora i modalnu linearnu analizu, tj linearno elastični model konstrukcije i redukovane spektre koji su već pomenuti. Uprošćenu metodu adekvatno je koristiti za objekte čiji je sklop takav da ispunjava određene uslove regularnosti, dok se modalna analiza može uvijek koristiti za sve tipove zgrada. Za konkretan slučaj analizirano je 12 tonova, pri čemu su ispoštovani svi zahtjevi propisa tako da je više od $90 \%$ mase izocilovalo, te su obuhvaćeni svi tonovi sa više od 5\% mase. Pritom nisu uočena nikakva odstupanja ili neregularnosti u oblicima oscilovanja te je većina mase bila obuhvaćena već u prva 3-4 tona. Što se tiče redukcije krutosti zbog isprskalosti presjeka nakon opterećenja, ona je unaprijed usvojena na način na koji to Evrokod standard sugeriše. Savojna i smičuća krutost redukovana je direktno za 50\% smanjenjem modula elastičnosti, a torziona je redukovana 10 puta (preporuka je od 10 do 20). Aksijalnu krutost nema smisla smanjiti na taj nivo, pa se zbog smanjenog modula elastičnosti ona mora udvostručiti tako da je EA * 2. Ploče se posmatraju kao krute dijafragme, te nema redukcije krutosti. Modeliranje tla je izvršeno prema uobičajenoj proceduri za jednoparametarski, Winkler-ov model tla. Tlo se tretira kao elastična podloga sa proporcionalnim odnosom pritiska na tlo (q) i slijeganja (y) za svaki konačni element, što direktno zavisi od krutosti podloge (tla) . 


$$
\mathrm{q}=\mathrm{k} \cdot \mathrm{y}
$$

gdje je: k- koeficijent krutosti posteljice ili modul reakcije tla.

Ovo nije fizička veličina, već je prikazana kao odnos površinskog opterećenja i slijeganja i određuje se postupkom opita ploče. U master radu usvojena je vrijednost $15000 \mathrm{kN} / \mathrm{m}^{3}$ što je na strani sigurnosti, ali u praksi je to predmet istraživanja i dio je geomehaničkog elaborata.

\section{UPOREDNA ANALIZA I PRORAČUN KONSTRUKCIJE}

\subsection{Proračun i analiza stubova i greda}

Stubovi i grede (u ovom slučaju i seizmička platna) kao primarni elementi za prijem horizontalnih opterećenja su predmet analize jer se dimenzionisanje i armiranje ploča tipskog sprata i temeljne ploče vrši dominantno na osnovu gravitacionog opterećenja. Treba imati na umu da, u suštini, gravitacija ruši objekat pri zemljotresu, ali momenti na krajevima greda, stubova i u korijenu zidova potiču od horizontalnih sila. Kroz obradu teme master rada pokazalo se da su razlike u uticajima u pločama za $\mathrm{DCM}_{0,25 \mathrm{~g}} \mathrm{i} \mathrm{DCH}_{0,35 \mathrm{~g}}$ konstrukcije beznačajne što se vidi i po planu armiranja koji su identični za ove dvije konstrukcije. To nije slučaj za stubove i grede. Za DCH konstrukciju važe pravila nastavljanja i preklapanja šipki, formiranja čvorova, formiranje kritičnih zona, nivo utezanja presjeka itd.

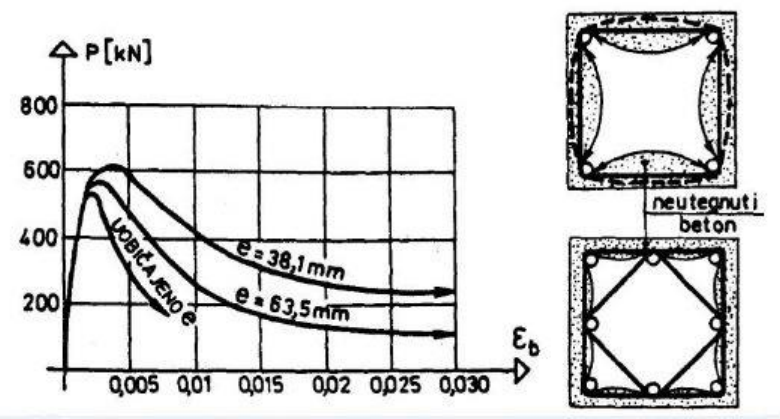

Slika 3. Grafička simulacija efikasnosti utezanja presjeka

Smanjiti razmake podužnih i poprečnih šipki i korišćenje manjeg prečnika, generalno je logika koja značajno pospješuje lokalnu i globalnu duktilnost konstrukcije. Sa slike 3. se to može lako zaključiti. Na slici 4. je prikazano po klasama duktilnosti šta to fizički znači - manja seizmička proračunska sila $\mathrm{i}$ veća granična dilatacija/ pomijeranje za različite klase duktilnosti prema Evrokodu. Kod višespratnih okvirnih konstrukcija, javlja se potreba da podužna armatura stuba nižeg sprata bude nastavljena armaturom gornjeg stuba. Uglavnom se to rješava prostim preklopom, čija dužina zavisi od klase betona i prečnika i klase armature koja se nastavlja. Mjesto preklopa počinje na prekidu betoniranja, neposredno iznad nivoa međuspratne konstrukcije. Česta je praksa da se sve šipke nastavljaju u istom presjeku, što udvostručuje broj šipki, smanjuje duktilnost presjeka, a i trajektorija sila je na neki način poremećena. Osim toga, to su upravo kritične zone koje se posebno utežu uzengijama radi postizanja duktilnosti i nema smisla narušavati ih. Iako Evrokod standard eksplicitno ne zabranjuje ovaj postupak, inženjerska logika vodi ka nekim praktičnim, dobrim rješenjima. Domaća praksa, u slučaju kada se dosta pažnje posvećuje detaljima i kada se radi o dobrom izvođenju, koristi rješenje da pola stubova prekida na jednom spratu, a drugu polovinu na sljedećem. Dobro rješenje jeste i da se armatura vodi kroz 2 etaže, i to na način da se polovina armature nastavlja u jednom presjeku, a druga polovina tek za 2 etaže. Time se eliminiše potencijalni „okidač“ konstrukcije u situacijama kada se najviše računa na stubove kao glavne seizmičke elemente.

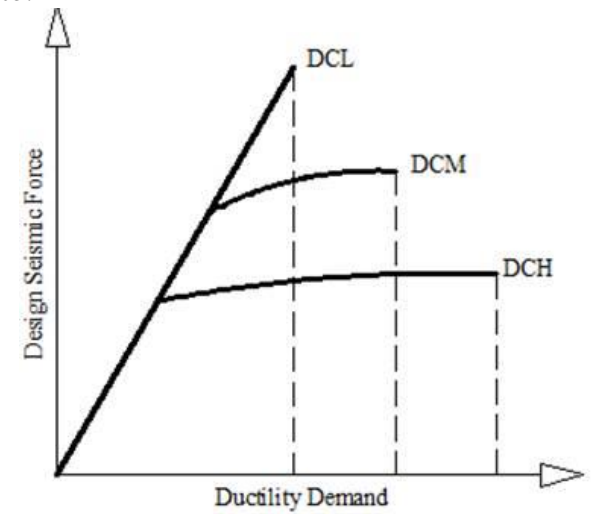

Slika 4. Prikaz odnosa projektne sile i zahtijevane duktilnosti

Sugeriše se, praksom i propisima, da se pri projektovanju ovakvih konstrukcija i usvajanju nominalne geometrije stubova i greda formira neki odnos krutosti stuba i grede. Poželjno je da stub ima veću krutost od grede, najčešće oko 10-30\%. Osim geometrijom, tj dimenzijama presjeka, to se postiže povećanjem količine i racionalnim oblikovanjem podužne i poprečne armature. Poznato je da veći uticaji teže ka presjeku veće krutosti. Praktično to znači da je preraspodjela momenata savijanja usklađena sa odnosom predmetnih krutosti.

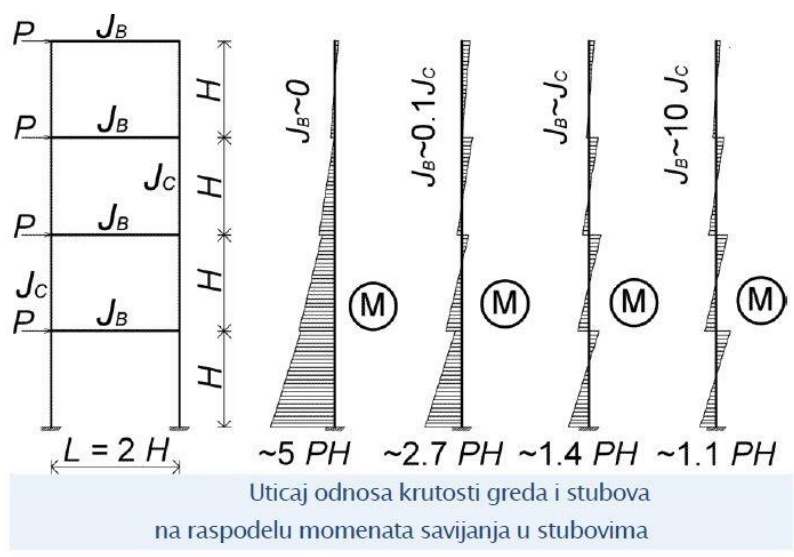

Slika 5. Dijagram , $M$ “ za različite odnose krutosti stubgreda

Za potrebe proračuna ove konstrukcije korišćen je odnos momentne nosivosti stuba i grede:

$$
\mathrm{M}_{\mathrm{Rdc}}=1,3 \cdot \mathrm{M}_{\mathrm{Rdb}}
$$

\subsection{Oblikovanje detalja}

Sve dimenzije stubova okvira različite spratnosti određene su, između ostalog, da zadovolje vrijednost normalizovane aksijalne sile $v_{\mathrm{d}}$, koja kod primarnih seizmičkih stubova DCH okvira ne smije biti veća od 0,55 , a kod 
DCM okvira 0,65. Okviri spratnosti 4 imaju vrednost $v_{\mathrm{d}}$ 0,23 , okviri spratnosti 60,28 , dok je kod okvira spratnosti 8 ova vrijednost 0,31 a kod okvira spratnosti $10,0,33$. Niža vrijednost normalizovane aksijalne sile doprinosi duktilnosti kod stubova. Kritične zone u gredama i stubovima se proširuju za DCH klasu u odnosu na DCM i time se osigurava da neće doći do pojave plastičnih zglobova baš na osjetljivim mjestima - spojevima grede i stuba. DCH konstrukcija u tim zonama ima šestosječne uzengije, dok DCM ima četvorosječne, što je uslovljeno brojem podužnih šipki. Pravila za DCH konstrukciju koja su nametnuta Evrokodom rezultovala su datom situacijom u kojoj duktilniji presjek ima veći broj šipki manjeg prečnika, od kojih je svaka pridržana uzengijom. Time se direktno postiže efikasnost utezanja presjeka što je ključ duktilnog ponašanja i sprječavanje pojave plastičnih zglobova u zonama najvećih fleksionih $\mathrm{i}$ aksijalnih uticaja.

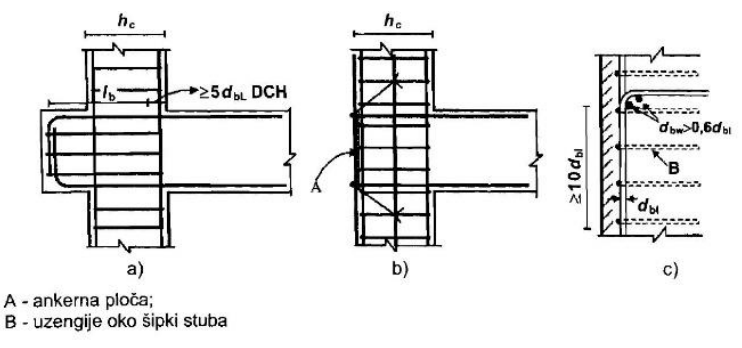

\section{Slika 6. Detalji sidrenja izuzetno opterećenih čvorova DCH konstrukcije}

Za ovu konstrukciju ovakvi detalji nisu formirani, jer se nije ukazala potreba za tim. Ciljano je usvojen veći broj šipki manjeg prečnika čime je smanjena dužina sidrenja, a povećana duktilnost. Širina stuba je veća od širine grede, tako da ni sa te strane nema potrebe za ovakvim oblikovanjem čvorova DCH konstrukcije. Osnovna načela po kojima EC8 vodi ka duktilnom ponašanju jeste ograničenje razmaka uzengija, razmaka podužnih šipki, minimalni i maksimalni prečnik šipke. Naravno, to je sve posljedica detaljnih istraživanja i pozadina takvih zaključaka je složena, a Evrokod nudi dovoljno objašnjenja za iste.

\section{KLJUČNE RAZLIKE I ZAKLJUČAK}

Već je spomenuto da je osnovna ideja klasifikacije konstrukcija prema duktilnosti nastala sa ciljem da se dobije racionalnije projektovana konstrukcija, sa postavljenim ograničenjima deformacija, pomijeranja i oštećenja. To bi značilo da se za isti nivo opterećenja (prema lokaciji, izvorima i prirodi opterećenja) smanji robusnost konstrukcije uz povećanje performansi dobrim projektovanjem i izvođenjem. Ipak, tema ovog rada nije bila da se postigne ušteda smanjenjem utroška materijala ili povećanje korisnog prostora unutar objekta, nego da se dokaže da se za istu geometriju (uz poštovanje propisa za DCH klasu) može dobiti sklop konstruktivnih i nekonstruktivnih elemenata koji će se izuzetno dobro ponašati $u$ vanrednim situacijama, npr $u$ slučaju prekoračenja projektnog ubrzanja tla.
Da bi ključna razlika bila jasnija, za nivo seizmičkog ubrzanja od $\mathrm{a}_{\mathrm{gR}}=0,25 \mathrm{~g}$, koje je dato mapom seizmičkog hazarda, postojeća konstrukcija DCM mogla bi se preprojektovati na DCH pri čemu bi se dobile manje sile u presjecima, samim tim možda i manji presjeci. Ipak, za tvrdnje da će se postići smanjen utrošak materijala potrebne su ozbiljne analize kojima treba naći ekonomsku opravdanost, što je malo izvijesno. Projektnim zadatkom je dokazano da za isti utrošak betona i armature i nešto složenije izvođenje, može da se postigne drastično veća otpornost i poboljšan odgovor na učestale, nepredviđene zemljotrese.

Kao zaključak može se navesti da je u današnje vrijeme sasvim pogrešno razmišljati o DCL klasi i projektovanju konstrukcije za elastičan rad. I dalje postoje nesuglasice $\mathrm{u}$ vezi sa tim da li se treba opredijeliti za srednju ili visoku klasu duktilnosti. U kontekstu toga i svih činjenica koje su u radu navedene, optimalizovana konstrukcija visoke klase duktilnosti nameće se kao logično rješenje za svaku ozbiljniju armiranobetonsku konstrukciju.

To se nesumnjivo odnosi na objekte poput ovog - za višeporodično stanovanje ili neke objekte gdje svakodnevno boravi mnoštvo ljudi, skladišti ili koristi skupa oprema... Optimalizovana DCH konstrukcija podrazumijeva pažljivo poboljšanu DCM konstrukciju izuzetnih performansi u nepredviđenim okolnostima, a ne težnju ka uštedi kroz maksimalnu iskorištenost materijala.

\section{LITERATURA}

[1] Đorđe Marjanović, „Odgovor armiranobetonske konstrukcije na ubrzanje tla veće od projektnog i uporedna analiza klasa duktilnosti prema Evrokod standardu - Master rad“, Novi Sad 2021. god.

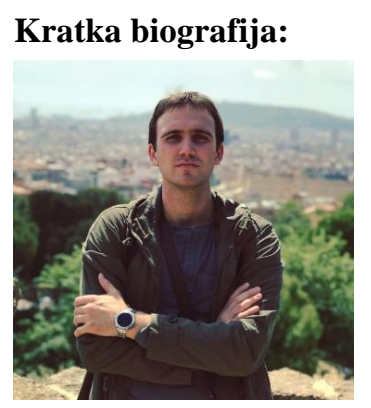

Đorđe Marjanović rođen je u Sremskoj Mitrovici 1995. godine. Diplomski rad odbranio je 2020. god. i master rad 2021. god. na Fakultetu tehničkih nauka $\mathrm{u}$ Novom Sadu, oba iz oblasti Građevinarstvo. 